\title{
The Church's Contextual Mission to Poverty Problems in Indonesia
}

\author{
Firman Panjaitan \\ Sekolah Tinggi Teologi Tawangmangu, Jawa Tengah, Indonesia \\ Email: panjaitan.firman@gmail.com
}

\begin{abstract}
Poverty in Indonesia is a crucial problem that must be considered by various parties, including the church. However, the church often neglects this because the church is often preoccupied with its theological model that sides with wealth so that the existence of the poor is ignored. This makes the church's mission neglected because it does not take the condition of the poor seriously. Using the phenomenological method, this article shows that poverty should be a severe concern in the missiological aspect of the church. In addition, the method of rhetorical criticism is used to show that the Bible also speaks of God's care for the poor. The study results recommend that the church should have the courage to carry out missiological duties to the poor by putting the poor first and placing the poor as equals, who also receive the same salvation from God. Through this missiological task, the church will contribute to alleviating poverty.
\end{abstract}

Keywords: Poverty; Church; Concern; Come First; Missiology.

\begin{abstract}
ABSTRAK: Kemiskinan di Indonesia merupakan masalah krusial yang harus diperhatikan oleh berbagai pihak, termasuk gereja. Namun seringkali gereja mengabaikan hal ini, karena gereja seringkali asyik dengan model teologinya yang berpihak pada kekayaan, sehingga keberadaan orang miskin diabaikan. Hal ini menjadikan tugas misiologi gereja terbengkalai karena tidak memperhatikan dengan serius keadaan orang miskin. Dengan menggunakan metode fenomenologi artikel ini menunjukkan bahwa masalah kemiskinan harus menjadi perhatian yang serius dalam aspek misiologi gereja. Di samping itu digunakan juga metode kritik retorik untuk menunjukkan bahwa Alkitab pun berbicara tentang kepedulian Allah terhadap orang miskin. Hasil penelitian merekomendasikan bahwa gereja harus berani menjalankan tugas misiologi kepada orang-orang miskin, dengan cara mendahulukan dan menempatkan orang miskin sebagai sesama yang sejajar, yang juga mendapatkan keselamatan yang sama dari Allah. Melalui tugas misiologi tersebut, gereja akan berkontribusi untuk mengentaskan kemiskinan.
\end{abstract}

Kata Kunci: Kemiskinan; Gereja; Kepedulian; Mendahulukan; Misiologi.

Article History: Submitted: 24 Februari 2021

Revised: 8 Mei 2021

Published: 27 Juli 2021

\section{PENDAHULUAN}

Secara sosial ekonomi mayoritas bangsa di Asia miskin, hal ini tampak dalam pesan yang ditulis oleh pertemuan Dewan Gereja-gereja Asia pada tahun 1980 di Kandy yang mengatakan bahwa Asia dilanda kemiskinan yang amat dahsyat, termasuk Indonesia (Yewangoe, 2015, pp. 9-10). Khususnya di Indonesia, kemiskinan terjadi akibat dari adanya 'campur tangan' pihak ketiga yang memiliki kepentingan terhadap proses perkembangan negara, sehingga dapat dikatakan bahwa kemiskinan di Indonesia terjadi karena proses pemiskinan (Budiman, 1996, pp. 27-28), dan proses ini tidak dapat dilepaskan dari sistem kapitalisme yang menciptakan proses pemiskinan terhadap Indonesia yang dipandang kurang memiliki kemajuan dari segi industrialisasi (Raharjo, 1996, pp. 58-59). Duchrow menambahkan bahwa penyakit-penyakit sosial yang terjadi di Indonesia, seperti kemiskinan, adalah akibat dari kapitalisme global yang disponsori negara-negara adidaya dan sistem ini sangat berpotensi untuk mendorong secara tak terkendali kegiatan ekonomi yang mengarah pada penimbunan modal semaksimal mungkin bagi pihak pemilik modal. Akibatnya, di satu sisi, terjadi penumpukan modal pada sebagian kecil masyarakat dan di sisi lain terjadi proses pemiskinan pada sebagian be- 
sar masyarakat yang bukan pemilik modal (Duchrow, 2000, p. 11). Proses pemiskinan ini menumbuhkan mentalitas 'mencari selamat', sehingga muncullah 'raja-raja kecil' yang berupaya untuk menghisap masyarakat dan sumber daya alam secara tidak bertanggung jawab, misalnya: penebangan hutan secara liar, sistem ijon, sistem monopoli produk, dominasi tender, dan lain sebagainya. Akibat dari semua ini, terciptalah 'penjajahan' dari pihak yang berkuasa dan memiliki modal ekonomi kuat terhadap pihak ekonomi lemah.

Secara umum ilmu-ilmu sosial membagi kemiskinan ke dalam dua jenis, yaitu: pertama, kemiskinan relatif, yaitu situasi yang diakibatkan oleh perbedaan pembagian pendapatan yang sangat mencolok antara berbagai lapisan atau kelas dalam masyarakat. Kedua, kemiskinan mutlak, yang menggambarkan bahwa kebutuhan-kebutuhan pokok yang primer seperti sandang, pangan, papan, kesehatan, kerja dan pendidikan dasar tak dapat terpenuhi. Ciri utama kemiskinan tersebut adalah ketidakberdayaan dan ketergantungan. Bila dilihat dari pemahaman ilmu-ilmu sosial di atas, kemiskinan di Indonesia mencakup kedua jenis di atas, dan dari sini dapat dilihat betapa parah kemiskinan yang terjadi di Indonesia (JB Banawiratma dan Muller, 1993, pp. 126-128).

Secara hakikat, Pieris (1996, p. 47) mengungkapkan bahwa masalah kemiskinan merupakan masalah yang memiliki keterkaitan sangat erat dengan masalah mamon (uang, ekonomi), sehingga kemiskinan dapat dipandang sebagai: pertama, kemiskinan sukarela yang merupakan pemerdekaan (tindak kebajikan) karena situasi miskin memang sudah menjadi pilihan dan jalan hidup (hal ini tampak dalam pola kehidupan para rahib/biarawan yang memilih 'jalan kemiskinan' sebagai jalan hidupnya untuk menghayati kebersatuan mereka dengan Kristus yang miskin dan berada di tengah masyarakat yang miskin). Kedua, kemiskinan yang dipaksakan yang merupakan buah dosa. Ini adalah bentuk kemiskinan yang dipaksakan dan pada akhirnya akan melahirkan penderitaan secara fisik maupun psikis. Pendapat ini disetujui dan dikembangkan oleh Yewangoe (2015), yang mengatakan bahwa tidak semua bentuk kemiskinan melahirkan penderitaan karena ada kemiskinan yang sengaja diterima dengan berani, bahkan dipandang sebagai cara untuk menghayati kehidupan. Tetapi Yewangoe juga mengakui bahwa kemiskinan yang terjadi di Indonesia adalah akibat dari struktur masyarakat yang menindas dan hal ini dilakukan secara sistematis sehingga mereka (rakyat miskin) jatuh ke dalam sikap fatalistis yang menganggap bahwa kemiskinan dan penderitaan adalah nasib mereka dan tak ada jalan lain untuk mengubahnya. Dalam hal ini, kemiskinan ini tidak terpisahkan dari masalah keadilan. Apabila semua pemahaman dan pengertian kemiskinan di atas digabungkan, maka pada dasarnya akan ditemukan tiga faktor yang menyebabkan kemiskinan, yaitu ketidakadilan struktural, penindasan sistem kapitalis dan perampokan sistematis terhadap kekayaan negara (Yewangoe, 2015).

Penelitian ini akan menyoroti dan mengangkat masalah kemiskinan sebagai bagian dari penderitaan masyarakat yang diakibatkan oleh situasi dan struktur sosial yang tidak adil, sehingga masalah ini menjadi persoalan mendesak untuk diperhatikan oleh gereja-gereja di Indonesia. Hal ini tidak berarti bahwa peneliti menafikan bentuk kemiskinan sukarela, namun peneliti membatasi kajian mengenai kemiskinan yang diakibatkan oleh ketidakadilan situasi sosial sebagai konsentrasi dan fokus penelitian paper ini guna mengembangkan tindakan misiologi yang kontekstual sesuai dengan situasi kemiskinan di Indonesia.

\section{METODE}

Pembahasan dalam artikel ini menggunakan metode fenomenologi, karena fokus dalam penelitian ini berangkat dari fenomena kemiskinan yang ada, dan metode ini dapat menggambarkan makna dari pengalaman hidup yang dialami dalam kondisi kemiskinan secara langsung (Kuswarno, 2009, p. 22). Fenomena kemiskinan ini akan digali dan didapatkan melalui, pertama, Penelitian Pustaka (literature research) guna menghadirkan fakta-fakta kemiskinan yang sedang terjadi di Indonesia dan kedua, melalui pengalaman dan pengamatan langsung dari peneliti 
selama penelitian berlangsung (Zuhdiyaty, 2017). Selain itu, untuk meneliti bagian Alkitab maka metode yang dipakai adalah kritik retorik yang merupakan bentuk kritik yang mempekerjakan prinsip-prinsip retorika untuk meneliti interaksi antar teks, peneliti dan pembaca teks. Metode kritik retorik bertujuan hendak menciptakan satu kesatuan jenis sastra dari banyaknya inter-tekstualitas baik kepada teks-teks Alkitab maupun teks-teks ekstra biblika, untuk menemukan makna yang lebih menyeluruh, sehingga pembaca dapat memahami apa yang menjadi berita dari teks-teks dalam Alkitab (Tridarmanto, 2013, p. 38). Melalui studi ini, peneliti akan melihat adanya hubungan komunikatif antara teks dengan pembaca sehingga didapat pesan utama dari teks yang peneliti teliti. Dengan melihat kait kelindan antara metode fenomenologi dan kritik retorik akan ditemukan makna untuk membangun sebuah tindakan misi kontekstual dalam konteks Indonesia (masa kini).

\section{HASIL DAN PEMBAHASAN}

\section{Teori tentang Ketidakadilan Sosial}

Terdapat beberapa teori tentang kemiskinan yang diakibatkan ketidakadilan struktur sosial. Aristoteles, dengan teori Sistem Kelas, melihat bahwa manajemen dalam rumah tangga terdiri dari tiga bagian, yaitu: pertama, nisbah antara tuan - budak yang menunjukkan kekuasaan despotik. Kedua, nisbah antara suami - istri yang menunjukkan kekuasaan perkawinan. Ketiga, nisbah antara ayah (orang tua) anak yang menunjukkan kekuasaan paternal. Ketiga bagian ini ada dalam hierarki kepemilikan yang menggambarkan bahwa seorang budak, istri dan anak dalam rumah tangga adalah milik dari suami sekaligus ayah yang juga adalah seorang tuan. Dalam manajemen ini perbudakan dipandang sebagai bentuk kewajaran yang alamiah (Rowe \& Schofield, 2001, pp. 390-395).

Panjaitan (2018) mengungkapkan bahwa situasi rumah tangga ini menjadi gambaran umum bagi sistem kemasyarakatan, yang pada akhirnya menciptakan hierarki dalam pola hubungan orang kaya (tuan) dan orang miskin (budak). Dalam situasi hierarkis ini, kondisi orang miskin (budak) berada dalam situasi yang tidak adil, tetapi mereka tidak bisa keluar dari situasi yang telah mengikat/memenjara mereka. Terlebih ketika disadari bahwa kondisi sosial tersebut dipandang sebagai bentuk struktur alamiah (yang bersifat natural), maka kemiskinan tidak akan pernah bisa menembus jaringan sistem sosial/kemasyarakatan yang ada untuk merambah naik ke jenjang sosial yang lebih tinggi lagi, karena pada hakikatnya hidup setiap orang miskin (budak) adalah milik dari orang kaya (tuan) dan sangat tergantung atas belas kasihan dari para majikan. Aristoteles merasa pesimis terhadap perubahan struktur sosial dalam kehidupan manusia.

Teori Determinisme menegaskan bahwa nasib, kondisi dan situasi manusia baik secara perorangan maupun komunal telah dideterminisasi (ditentukan) secara religius, fisiologis maupun sosiologis (Mangunhardjana, 1997, pp. 41-43). Determinisme tidak membuka peluang bagi kebebasan manusia, sehingga kondisi yang dialami oleh manusia bukan hasil pilihan dan keputusan manusia melainkan ditentukan oleh garis nasib mereka; ini berarti Determinisme menempatkan manusia sebagai makhluk yang 'tidak bebas' dalam menentukan masa depannya.

Dalam perkembangannya, paham Determinisme memandang bahwa pola kehidupan manusia dalam bermasyarakat ditentukan oleh pihak-pihak yang 'berhak menentukan' nasib masyarakat, yaitu pihak yang berkuasa/memegang pimpinan. Legalisasi sistem sosial kemasyarakatan diterima sebagai sebuah nasib yang memang harus ditanggung oleh manusia (Baharudin, 2014). Pola ini nampak jelas dalam kehidupan bermasyarakat di Indonesia, di mana setiap masyarakat 'kelas bawah' selalu mengatakan bahwa kehidupan yang mereka jalani sekarang sudah menjadi garis nasib mereka dan mereka hanya bisa nrimo (pasrah tanpa kekritisan). Hal ini sangat menguntungkan pihak penguasa, karena sikap nrimo masyarakat 'kelas bawah' akan mendorong pihak 
penguasa berani membuat sistem yang mengatur hidup dan nasib para rakyat yang dipimpinnya.

Setelah Perang Dunia I (tahun 1929 ke atas), di Amerika Utara muncul gerakan Kristen baru yang hendak menyoroti kehidupan kekristenan di Amerika. Mereka menamakan diri sebagai kelompok Social Gospel yang mengajarkan bahwa upaya manusia untuk lepas dari kuasa dosa yang bisa dilakukan bila manusia memiliki keterikatan yang erat dengan Allah sebagai penentu bagi kehidupan manusia. Allah juga dipandang sebagai penentu kehidupan manusia dalam masalah sosial, sehingga Social Gospel mengatakan bahwa situasi kaya dan miskin yang dialami oleh manusia adalah kehendak Allah yang tidak dapat diganggu gugat. Social Gospel menekankan bahwa Allah yang menciptakan kemiskinan (Schweitzer, 1999, pp. 50-56).

Namun pandangan Social Gospel menjadi bumerang bagi masyarakat yang hidup di bawah garis kemiskinan, karena dengan legalisasi bahwa Allah yang menjadi penentu bagi nasib manusia maka hal ini dimanfaatkan oleh kaum pemilik modal dan penguasa untuk semakin menindas mereka dengan menggunakan legitimasi 'di dalam nama dan atas kehendak Allah'. Social Gospel juga telah menciptakan teori yang mendukung terbentuknya sistem kelas dalam masyarakat.

Sebagai reaksi atas pandangan Social Gospel, di Amerika Latin muncul Teologi Pembebasan yang berpandangan bahwa kemiskinan adalah akibat dari struktur masyarakat yang tidak adil. Teologi Pembebasan menekankan bahwa kemiskinan yang terjadi adalah akibat dari 'pembagian kue' yang tidak merata dan ini akibat dari 'kucuran air' yang diberikan dari atas telah mengalami pendistribusian terlebih dahulu di bagian atas sebelum didistribusikan ke bawah (rakyat). Jelas sekali di sini bahwa kemiskinan yang dialami oleh masyarakat kelas bawah adalah akibat dari ketidakadilan sosial yang bermula dari struktur/ tatanan masyarakat yang tidak adil. Mengatasi kemiskinan dilalui dengan cara mengubah struktur sosial dan tatanan kemasyarakatan secara radikal. Pemerintahan harus dikendalikan oleh rakyat dan rakyat yang menjadi penentu bagi kehidupan negara (Elizondo, 1999, pp. 107-110).

Dari beberapa teori di atas, dapat dilihat bahwa masalah kemiskinan di dunia tidak pernah lepas dari masalah struktur sosial masyarakat, dan lebih khusus lagi mengenai sistem sosial yang membagi masyarakat dalam kelas-kelas yang berbeda. Meskipun cara pandang teori-teori itu berbeda, namun memiliki kesamaan yaitu: kemiskinan adalah akibat struktur sosial masyarakat yang tidak adil sehingga memunculkan sistem kelas yang menggambarkan hierarki dalam kehidupan bermasyarakat. Melalui hierarki sosial, kehidupan bermasyarakat telah ada dalam cengkeraman sistem kepemilikan, di mana pihak yang memiliki kekuatan dan kekuasaan secara de facto menjadi pemilik atas pihak masyarakat yang tidak memiliki kekuatan dan kekuasaan. Dengan demikian, kemiskinan bukanlah nasib/takdir ataupun karena struktur alamiah dalam kehidupan masyarakat (Walzer, 1983, pp. 10-13).

\section{Gereja dan Kemiskinan}

Dalam sejarah, Gereja mengalami perubahan orientasi teologis setelah Perang Dunia I, karena dalam masa-masa itu gereja mengalami pergumulan yang berat mengenai kegagalan kekristenan dalam memenuhi panggilannya selaku orang-orang kudus. Hal ini menjadi pergumulan bagi Richard $\mathrm{H}$ Niebuhr, yang dituangkan dalam bukunya Christ and Culture (Hall, 1999, pp. 40-45). Di samping pergumulan mengenai kegagalan kekristenan tersebut, gereja pun mengalami pergumulan baru, yaitu yang menyangkut masalah kemiskinan, karena setelah Perang Dunia I berakhir, jumlah orang miskin di dunia semakin tampak ibarat gunung yang menjulang. Pergumulan ini menjadi serius, ketika gereja menyadari panggilan misiologisnya untuk hidup di antara orang miskin dan menjadi garam dan terang kehidupan. Gereja mulai menyadari panggilannya selaku 'nabi' bagi orang miskin dan membawa berita pengharapan kepada setiap lapisan masyarakat yang potensial untuk dilupakan (Elizondo, 1999). Dalam kesadaran panggilan misiologis selaku gereja bagi orang miskin, gereja 
selayaknya memperhatikan dan melibatkan orang miskin dalam membangun dan mengembangkan teologi (Elizondo, 1999), karena pada dasarnya upaya berteologi adalah upaya yang selalu ditujukan kepada rakyat (orang miskin) (Panjaitan \& Siburian, 2019). Dengan kata lain, teologi dapat berkembang bila berhubungan langsung dengan situasi yang seringkali disebut problematic theology, yaitu orang yang menderita, karena harus dipahami bahwa Yesus pun adalah Allah dari rakyat yang menderita (Allah sebagai pemilik hati yang remuk). Dengan demikian apabila gereja hendak berbicara tentang teologi Yesus hendaknya disadari bahwa teologi tersebut harus selalu didaratkan dalam kehidupan teologi rakyat yang menderita bersama dengan Yesus (Setiawan, 2018).

Dengan menyadari hal di atas, maka sesungguhnya teologi bukan hanya berbicara tentang masalah di sekitar surga, melainkan harus juga menyentuh masalah-masalah duniawi (Song, 1979, pp. 59-61). Teologi yang tidak mengalami situasi kerakyatan nyata dapat diibaratkan sebagai 'paku yang dipasang di awang-awang'. Oleh sebab itu, gereja yang tidak memedulikan orang miskin gereja yang mempraktikkan tindakan kekerasan terhadap kehidupan karena telah melupakan jati diri dan misinya selaku bagian dari orang miskin (Gultom, 2018). Gereja harus mengingat bahwa keberadaannya di dunia adalah sebagai peneladan Yesus yang ber-kenosis (mengosongkan diri) dalam kehidupan manusia tanpa mengingat kedudukannya selaku Allah Yang Maha Tinggi. Dengan demikian gereja selayaknya memiliki spiritualitas kenosis, seperti Allah yang telah berkenosis di dalam diri manusia, yaitu Yesus Kristus (Voss Roberts, 2019).

\section{Sikap Allah terhadap Kemiskinan dalam Alkitab}

Bagaimana sikap etis dan misiologis yang harus ditumbuhkembangkan gereja dalam menghadapi realitas kemiskinan? Terlebih dahulu peneliti akan menjabarkan mengenai sikap Allah dalam menanggapi realitas kemiskinan dengan didasarkan atas narasi-narasi dalam Injil Matius. Peneliti melihat bahwa dalam beberapa bagian narasi Injil Matius hendak ditampakkan sikap dan kepedulian Allah sekaligus sikap misiologi-Nya terhadap orang miskin, oleh sebab itu pada bagian ini akan ditinjau apa yang dikandung dalam narasi-narasi Injil Matius mengenai kepedulian Allah (dalam hal ini diwakili oleh Yesus Kristus) terhadap realitas kemiskinan.

\section{Matius 5-7: Khotbah di Bukit}

Suharyo (1987, pp. 76-77) mengatakan bahwa bagian ini lebih tepat dikatakan sebagai bentuk 'ucapan selamat' kepada setiap orang yang diperkenan oleh Allah. Karena jika diamati Matius 5-7 dapat dikatakan sebagai pemenuhan segala janji Allah dalam Perjanjian Lama melalui kehadiran Yesus Kristus sebagai Allah yang terwujud dalam Perjanjian Baru, yaitu hadirnya Kerajaan Allah di dalam diri Yesus Kristus yang membawa berita damai sejahtera bagi setiap orang yang mengalami penindasan, karena melalui berita ini hendak digambarkan bahwa Allah sungguh-sungguh masuk ke dalam sejarah keselamatan manusia (Stassen, 1992, pp. 39-40).

Dalam berita Matius, Yesus digambarkan sebagai Kerajaan Allah yang mewujud dan telah memberikan perintah baru agar manusia hidup dalam style yang baru, God's style, yaitu hidup di dalam pendamaian dan penyatuaan diri dengan Allah dan kehidupan (Stassen, 1992). Dengan demikian kehidupan manusia harus menampakkan kebersatuannya dengan sesama sebagai wujud nyata dari kebersatuannya dengan Allah. Gambaran yang dipakai oleh Yesus untuk menunjukkan penyatuan diri manusia dengan Allah adalah melalui ungkapan, "Berbahagialah orang yang miskin di hadapan Allah (di dalam Roh) ..." (Patandean, 2018). Kalimat ini bukan berarti bahwa situasi miskin telah menjadi cita-cita bagi setiap orang yang berkenan di hadapan Allah, melainkan hendak menunjukkan bahwa setiap orang yang hidup dalam kebersatuan bersama dengan Allah adalah orang yang memiliki sikap ketundukan, kepasrahan dan kepercayaan yang utuh kepada tuannya yang dipandang sebagai pemilik kehidupannya, seperti halnya sikap yang ditunjukkan oleh setiap orang miskin, yang tidak memiliki apa pun kecuali ketun- 
dukan dan kepasrahan terhadap tuan yang memiliki kehidupan mereka (Suharyo, 1987).

Ucapan selamat berpuncak pada Matius 7:12 (The Golden Rule) yang menggambarkan bahwa setiap orang yang telah menjalani hidup di dalam kebersatuannya dengan Allah adalah orang yang proaktif dan selalu memulai apa yang dianggap baik, bukan sebagai upaya untuk mencari nama melainkan sebagai tanggung jawabnya kepada Allah yang telah menyatu dengan dirinya. Dengan demikian keberadaan orang yang bersatu dengan Allah adalah menjadi garam dan terang dunia (Mat. 5:13-16), sebagai orang yang selalu berdamai dengan orang lain tanpa ingin menghakimi yang lain (Mat. 7:1-5) dan selalu menghargai kehidupannya sendiri (Mat. 7:6) sehingga setiap doa yang diucapkan pasti dikabulkan Allah (Mat. 7:7-11) (Patandean \& Hermanto, 2019).

Dari uraian di atas nampak bahwa Matius 57 mau menggambarkan kepedulian Allah kepada seluruh manusia, termasuk kepada setiap orang yang tidak berdaya (ochlos - rakyat miskin), yang merupakan bagian dari masyarakat yang tidak memiliki apa pun kecuali kepasrahan yang total kepada tuan si pemilik kehidupan mereka.

\section{Matius 22:37-40 - Khotbah tentang Kasih}

Bagian ini adalah penegasan terhadap bagian di atas (Mat. 5-7), yang menekankan bahwa kasih kepada Allah hanya dapat diwujudnyatakan dalam kasih kepada sesama manusia. Kasih kepada Allah bukan kasih yang irasional melainkan rasional, karena mengasihi Allah juga dilakukan dengan menggunakan pengetahuan dan akal budi. Bagian ini juga menjelaskan bahwa Allah selalu mewujud dalam setiap aspek kehidupan manusia (yang meliputi tubuh, jiwa, akal budi, dan roh manusia). Apabila manusia hendak mengasihi Allah, maka perwujudan kasih ini harus tampak dalam setiap aktivitas manusia, yaitu mengasihi setiap aspek kehidupan, termasuk dalam bidang pekerjaan yang digelutinya selama ini (Panjaitan \& Siburian, 2019). Jika demikian, kasih kepada Allah yang bernuansa vertikal sebenarnya juga memiliki nuansa horizintal, terlebih ketika Yesus mengatakan bahwa hukum yang kedua, yaitu mengasihi manusia seperti mengasihi diri sendiri, itu sama dengan hukum yang pertama. Ini berarti kedua hukum ini adalah sejajar, satu dan tidak dapat dipisahkan. Pengalimatan ini menegaskan bahwa upaya untuk mengasihi Allah tanpa pewujudnyataan melalui upaya mengasihi manusia adalah sia-sia dan hal itu sama dengan menipu diri sendiri (bdk. I. Yoh. 4: 20).

Dalam bagian ini tampak sekali nuansa ilahi yang manusiawi dan sekaligus nuansa manusia yang ilahi dalam diri Yesus melalui pemberian hukumNya. Yesus menekankan bahwa kehidupan yang dijalani manusia haruslah menunjukkan kebersatuan di dalam kehidupan bersama dengan sesama, sebagai manifestasi langsung dari kesatuan hidup manusia dengan Allah. Dalam hukum ini tampak teologi Salib Yesus, yaitu hukum yang vertikal (mengasihi Allah) bertemu dengan hukum yang horizontal (mengasihi sesama) dalam satu kesatuan. Melalui teologi salib ini Yesus hendak menekankan bahwa kasih yang diajarkan Allah kepada manusia adalah kasih yang tidak pernah membedakan, karena setiap orang adalah sesama bagi manusia.

\section{Matius 25:31-46 - Khotbah Akhir Jaman}

Setelah pembicaraan mengenai kasih kepada sesama sebagai wujud nyata kasih kepada Allah secara umum, maka bagian ini menekankan unsur kasih secara khusus. Penggambaran mengenai Yesus/Allah yang hidup di dalam diri orang yang menderita, miskin, papa, terbuang dan yang mengalami ketidakadilan, merupakan penggambaran yang diberikan agar setiap orang mau peduli dan memperhatikan mereka yang tersisih dan terbuang. Dalam konteks masyarakat, di mana orang miskin dipandang sebagai warga negara kelas dua, maka yang menjadi kebutuhan utama mereka adalah pembelaan. Pembelaan tidak akan pernah mereka rasakan apabila mereka dibiarkan berjuang sendiri. Tetapi pembelaan akan terjadi apabila ada orang-orang yang mau berjuang dan berprihatian serta peduli kepada mereka. Untuk itulah Yesus mengidentifikasikan dirinya selaku orang- 
orang yang tidak memiliki peluang dalam kehidupan. Inilah yang disebut oleh CS Song sebagai Kristus sebagai Allah pemilik hati yang remuk (Song, 1979).

Identifikasi Yesus sebagai orang yang papa, terbuang dan tersisih, bertujuan hendak mengetuk hati semua orang untuk melihat bahwa Yesus hidup di dalam diri anggota masyarakat miskin, oleh sebab itu sasaran utama dalam hal mengasihi dan peduli adalah mereka yang miskin, papa, hina dan terbuang. Hal ini berarti bahwa kasih yang ditumbuhkan oleh setiap pengikut Kristus adalah kasih yang selalu berpihak, kasih yang mendahulukan dan kasih yang berprioritas, khususnya kepada orang-orang yang dipandang terbuang dari masyarakat (Panjaitan \& Siburian, 2019). Jika orang Kristen berani membela hak setiap orang kecil dan sekaligus mau mengasihi rakyat yang miskin, terbuang dan menderita akibat situasi sosial yang tidak adil, hal itu berarti bahwa mereka pun telah mengasihi dan peduli kepada Allah.

\section{Sikap Misiologis Gereja terhadap Kemiskinan}

Berdasarkan uraian di atas, maka beberapa pokok pikiran mengenai tugas misiologi gereja dalam menanggapi dan berjuang terhadap kemiskinan yang ada, khususnya di Indonesia, dapat diuraikan sebagai berikut:

\section{Gereja Harus Menjadi Komunitas Basis Bagi Penumbuhan Nilai-Nilai Kemanusiaan}

Dalam kehidupan yang telah diwarnai dengan pola hierarki, upaya mencari keadilan dan kesetaraan antar setiap golongan menjadi sesuatu yang harus diperjuangkan. Perjuangan ini dilakukan untuk mencari nilai keadilan dalam sistem kemasyarakatan, karena dalam kenyataannya hierarki sosial dalam sistem kemasyarakatan pada dasarnya telah menghapus (menafikan) nilai-nilai kemanusiaan (Artanto, 1997, pp. 67-69). Hierarki sosial menciptakan sistem kelas dalam masyarakat, akibatnya di satu sisi ada bagian dalam diri masyarakat yang diuntungkan oleh sistem kelas (kelas atas: penguasa dan pemilik modal), di sisi lain ada yang dirugikan (kelas bawah: orang miskin dan para pekerja/buruh)
(Tobar et al., 2020). Terjadilah kesenjangan sosial di segala bidang kehidupan (IPTEK, ekonomi, politik, sosial dan budaya). Apabila situasi ini dipertahankan terus, maka kehidupan akan mengalami degradasi di mana nilai-nilai kehidupan manusia telah tidak ada harganya sama sekali dan pelanggaran terhadap hak asasi manusia akan semakin memuncak.

Dalam situasi ini panggilan misiologis gereja adalah mengembalikan nilai-nilai kehidupan yang selama ini telah diselewengkan sedemikian rupa melalui sistem kelas. Gereja harus menampakkan diri sebagai bagian dari komunitas masyarakat yang tidak hidup di dalam sistem kelas (Metzger, 2013, pp. 298 299). Semua anggota dalam gereja hidup secara egaliter dan setara. Gereja harus menampakkan tataran kehidupan yang saling menghargai dan menghormati nilai kemanusiaan dan hak asasi sesama anggota (Hutagalung, 2016). Model kehidupan yang dikembangkan gereja dalam hidup komunitasnya, pada akhirnya akan melebar dan meluas menuju pada model kehidupan bermasyarakat.

Setiap anggota gereja harus menyadari bahwa dirinya adalah manusia yang telah dipanggil dan diutus ke dalam dunia untuk mengembalikan tata kehidupan bermasyarakat yang harmonis melalui sikap yang menghargai dan menghormati nilai-nilai kehidupan, dan tugas serta panggilan ini harus dipahami sebagai way of life setiap anggota gereja (Hery Susanto, 2019). Sikap yang menghargai dan menghormati nilai-nilai kehidupan dapat menjadi presure bagi kehidupan yang didasarkan atas sistem kelas yang tidak adil ini. Karena dalam kehidupan yang telah di-design dalam sistem strata masyarakat yang menafikan penghargaan dan penghormatan nilai-nilai kehidupan, model kehidupan baru yang menekankan tentang penghargaan dan penghormatan nilai-nilai kehidupan akan menjadi 'air penyejuk' yang di tengah padang pasir yang gersang, sekaligus sebagai model yang ingin memberontak terhadap sistem kelas dalam masyarakat.

Dalam hal inilah gereja harus berperan. Gereja harus berani membangun dirinya sebagai komunitas basis yang mengajarkan dan menekankan 
unsur penghargaan dan penghormatan terhadap nilainilai kehidupan, tetapi sekaligus berani untuk menyuarakan suara kenabian dalam mengembalikan kesejajaran dalam tata kehidupan bermasyarakat. Suara ini harus berani disampaikan di gereja, baik dalam khotbah, gaya hidup maupun melalui tulisan-tulisan di media massa agar tawaran kehidupan yang didasarkan atas kasih dan kesetaraan dapat dikenal oleh masyarakat secara luas.

\section{Gereja Harus Menjadi Sahabat dan yang Mendahulukan Orang Miskin}

Sebagai pejuang yang ingin mengembalikan tata kehidupan bermasyarakat yang harmonis dengan didasarkan atas kesetaraan hidup, gereja harus memiliki sikap kasih yang dibangun atas dasar kasih yang agresif, memihak dan adil. Dalam pengertian, kasih yang ditampilkan gereja adalah kasih yang ingin menohok nilai kehidupan yang didasarkan atas ketidakadilan dan penyingkiran beberapa bagian anggota masyarakat yang dipandang hina, papa dan miskin. Gereja harus berani merangkul dan mengutamakan pelayanannya kepada bagian masyarakat yang seperti ini, karena dalam keteladanannya untuk mengikuti Kristus, gereja harus menyadari dirinya sebagai komunitas yang hidup dan berbagi kasih dengan mereka yang miskin, papa, hina dan tertindas (Peters, 2006, pp. 254-255).

Demikian juga dalam kehidupan liturgi (nyanyian kehidupan), gereja harus selalu menyertakan setiap orang miskin untuk terlibat aktif dalam menghidupi suasana liturgi (Febriana, 2020). Gereja bukanlah milik orang kaya saja, tetapi gereja pun bukanlah milik orang miskin. Gereja adalah milik Kristus, sehingga semua orang yang ada dalam komunitas gereja, tanpa memandang strata kehidupan, adalah milik Kristus (Panjaitan \& Lumingkewas, 2019). Dengan demikian hak untuk melantunkan liturgi dalam gereja pun dimiliki oleh lapisan anggota masyarakat yang miskin, bukan hanya orang-orang yang kaya. Di dalam gereja, dominasi dan monopoli adalah 'haram' di mata Tuhan dan manusia (Herry Susanto, 2019).
Jika gereja telah membangun dirinya sebagai sahabat bagi orang miskin, maka dalam kehidupan selanjutnya gereja pun dipanggil untuk memperjuangkan hak-hak orang miskin, hina, papa, dan tertindas ini dalam kehidupan masyarakat yang lebih luas. Gereja harus berani memposisikan dirinya sebagai pembela kaum miskin dan sekaligus memberikan presure kepada pemerintah, baik melalui refleksi kehidupan yang ditulis di media massa ataupun ikut terlibat langsung dalam aksi yang mendesak pemerintah agar pemerintah mau memperhatikan nasib setiap orang miskin, yang seringkali menafikan dan menghina keberadaan orang-orang miskin. Gereja harus berani berdiri di sisi yang sama dengan orang miskin, karena orang miskin bukanlah objek kehidupan di sebuah negara, mereka pun adalah subjek kehidupan dalam negara (Tomatala, 2003).

Dalam keberpihakannya kepada orang miskin, gereja harus berani memposisikan diri sebagai komunitas yang selalu mendahulukan orang miskin, dalam pengertian: gereja harus berani menempatkan mereka (orang miskin) terlebih dahulu sebagai 'sasaran pendampingan' gereja. Dengan menempatkan kelompok miskin sebagai hal yang terutama, gereja telah melibatkan dan mengikutsertakan mereka secara aktif dalam kehidupan bergereja (Nugroho, 2019). Keterlibatan orang miskin bukan hanya ada dalam keterlibatan aktivitas gerejawi saja, melainkan juga ikut terlibat dalam membangun teologi kehidupan gerejawi, karena dari orang miskin inilah gereja dapat belajar tentang kehidupan. Dengan demikian setiap liturgi yang dibangun gereja adalah liturgi kehidupan yang mendasarkan napas ilahi berdasarkan pengalaman hidup.

Pengalaman gereja yang selalu mendahulukan orang miskin pada gilirannya akan menjadi kekuatan utama dalam membangun sikap terhadap nilai-nilai ketidakadilan dalam tata kehidupan bermasyarakat. Karena pengalaman tersebut akan memampukan gereja memiliki 'pisau analisis sosial yang tajam' yang disertai dengan 'ketajaman refleksi kehidupan'. Dengan berbekalkan dua 'senjata' di atas, gereja dapat berkiprah dan tampil dalam ma- 
syarakat sebagai komunitas yang membawakan suara kebenaran dan keadilan Allah (Wibowo, 2015). Dalam hal ini suara gereja bukanlah suara yang ngawur, karena suara yang digelar gereja merupakan hasil kajian analisis yang tajam dan telah direfleksikan terlebih dahulu di dalam nilai-nilai kehidupan. Hal ini juga yang akan memampukan gereja untuk tampil dalam setiap aksi secara berani, bukan karena ingin mendapat pengakuan dan nama dari masyarakat atau pemerintah melainkan sebagai bentuk pewujudnyataan way of life gereja yang hidup dan ada bersama dengan orang miskin, hina dan tertindas.

\section{Gereja Harus Menjadi Panutan/Teladan Kehidupan}

Dengan memandang bahwa penyatuan diri dan sikap untuk selalu mendahulukan orang miskin merupakan way of life gereja, maka sebenarnya gereja telah memperlihatkan kepada masyarakat bahwa gereja bukan hanya memiliki strategi dalam menghadapi permasalahan sosial, tetapi secara hakiki gereja adalah strategi sosial itu sendiri (Hauerwas \& William H. Willimon, 1989, pp. 43-47). Sebagai strategi sosial gereja telah menunjukkan sikap sebagai sebuah komunitas yang independen tanpa harus terpengaruh oleh setiap keputusan yang tidak adil, yang telah diberlakukan sekalipun oleh negara (Nugroho, 2019). Keberanian gereja dalam menempatkan dirinya sebagai strategi sosial yang menunjukkan independensinya haruslah diiringi dengan keberanian gereja untuk selalu mendobrak tatanan kehidupan sosial yang tidak adil dengan penekanan pada pewartaan mengenai kesetaraan hidup yang didasarkan atas sikap menghargai dan menghormati nilainilai kehidupan setiap orang tanpa pembedaan (Piper, 2003, pp. 210-211). Gereja harus berani untuk memproklamirkan diri sebagai komunitas yang selalu peduli terhadap keadilan dan melawan segala bentuk

\section{DAFTAR RUJUKAN}

Artanto, W. (1997). Menjadi Gereja Misioner dalam Konteks Indonesia. Kanisius-BPK Gunung Mulia. ketidakadilan dalam bidang kehidupan (Panjaitan \& Lumingkewas, 2019b), sehingga dengan keberaniannya tersebut gereja akan memainkan peranan penting dalam kehidupan bermasyarakat adalah sebagai tempat pendidikan moral secara praksis bagi warga gereja secara khusus dan bagi masyarakat secara umum.

\section{KESIMPULAN}

Gereja yang memahami dirinya sebagai komunitas independen adalah gereja yang berani menolak tawaran untuk duduk dalam sistem pemerintahan, karena bila gereja hidup dan duduk dalam sistem maka suara keadilan gereja pun akan berubah, bukan suara keadilan Allah melainkan suara keadilan gereja yang didasarkan atas kepentingan. Kepedulian dan persahabatan gereja dengan orang miskin akan diganti dengan kepedulian dan persahabatan dengan kaum penguasa dan pemilik modal. Dengan demikian gereja harus berani memposisikan diri untuk tetap menjadikan dirinya sebagai komunitas independen yang bertugas sebagai 'kontrol sosial' bagi pemerintah, sehingga kepeduliannya dan persahabatannya dengan orang miskin tetap terjaga secara murni.

Gereja yang memainkan peranannya sebagai komunitas independen dan setia pada orang miskin telah menempatkan dirinya selaku teladan bagi kehidupan. Gereja menjadi peneladan utama Yesus Kristus, dan keberadaan gereja tidak terpisah dengan keberadaan Yesus Kristus yang selalu dekat dan menyatu dengan orang miskin. Dalam situasi ini gereja dapat berbicara kepada masyarakat, "Jika ingin belajar tentang kepedulian, kasih dan kehidupan, lihatlah pada gaya hidupku; seperti apa yang telah kulihat dalam gaya hidup Tuhanku, Yesus Kristus. Karena pada dasarnya inilah jalan hidup yang telah kupilih, hidup bersama dengan Yesus yang mewujud nyata dalam kehidupan bersama dengan orang miskin, hina, papa dan tertindas."

Baharudin, M. (2014). Konsepsi Ketuhanan Sepanjang Sejarah Manusia. Al-AdYan, 9(1), $35-58$. 
Banawiratma, J. B., dan Muller, J. (1993). Berteologi Sosial Lintas Ilmu. Kanisius.

Budiman, A. (1996). Kemiskinan, Pemiskinan, dan Peran Agama: Sebuah Peta Pemikiran. In J. Banawiratma (Ed.), Iman, Ekonomi \& Ekologi: Refleksi Lintas Ilmu dan Lintas Agama. Kanisius.

Duchrow, U. (2000). Mengubah Kapitalisme Dunia. BPK Gunung Mulia.

Elizondo, V. (1999). Emergence of a World Church and the Irruption of the Poor'. In G. Baum (Ed.), The Twentieth Century: A Theological Overview. Orbis Books.

Febriana, M. (2020). Pietas Dan Caritas : Pelayanan Diakonia Sebagai Suatu Implementasi Kepedulian Sosial Gereja Untuk Menolong Meretas Angka Kemiskinan Di Indonesia. SOLA GRATIA: Jurnal Teologi Biblika Dan Praktika, $2(2)$. https://doi.org/10.47596/solagratia.v2i2.26

Gultom, R. A. T. (2018). Kemiskinan (Kajian Teologi terhadap Pemahaman Orang Kristen). Jurnal Teologi Cultivation, 2(2), 464-469.

Hall, D. J. (1999). The Great War and the Theologians. In Gregory Baum (Ed.), The Twentieth Century: A Theological Overview. Orbis Books.

Hauerwas, S., \& William H. Willimon. (1989). Resident Aliens. Abingdon Press.

Hutagalung, S. (2016). Tugas Panggilan Gereja Koinonia: Kepedulian Allah dan Tanggung Jawab Gereja terhadap Kemiskinan. Jurnal Koinonia, 8(2), 93-102.

Kuswarno, E. (2009). Fenomenologi. Widya Padjadjaran.

Mangunhardjana, A. (1997). Isme-Isme dalam Etika dari A sampai $Z$. Kanisius.

Metzger, W. (2013). Beritakan Kebenaran. Momentum.

Nugroho, F. J. (2019). Gereja dan Kemiskinan: Diskursus Peran Gereja di Tengah Kemiskinan. Evangelikal: Jurnal Teologi Injili Dan Pembinaan Warga Jemaat, 3(1), 100-112. https://doi.org/https://doi.org/10.46445/ejti.v3i 1.128

Panjaitan, F. (2018). Kekerasan Terhadap Istri dalam Lingkup Domestik (Suatu Tinjauan Etis Kristiani Tentang Kekerasan Terhadap Keluarga). Fidei: Jurnal Teologi Sistematika Dan Praktika, 1(1), 42-67. https://doi.org/10.34081/fidei.v1i1.3

Panjaitan, F., \& Lumingkewas, M. S. (2019a). Ibadah Jemaat Kristen Kontemporer Abad 21 Dan Tinjauan Kritis-Liturgis. FIDEI: Jurnal Teologi Sistematika Dan Praktika, 2(1), 159-182. https://doi.org/10.34081/fidei.v2i1.49

Panjaitan, F., \& Lumingkewas, M. S. (2019b). Keadilan Dalam Hukum Lex Talionis: Tafsir Terhadap Keluaran 21:22-25. Pengarah: Jurnal Teologi Kristen, 1(2), 73-84. https://doi.org/10.36270/pengarah.v1i2.13

Panjaitan, F., \& Siburian, H. H. (2019). Misi Kristologi dalam Konteks Kebudayaan. Logia: Jurnal Teologi Pentakosta, 1(1), 42-59. https://doi.org/https://doi.org/10.37731/log.v1i 1.19

Patandean, Y. E. (2018). Pengajaran Tuhan Yesus Mengenai Berbahagia Dalam Matius 5:3-12. Evangelikal: Jurnal Teologi Injili Dan Pembinaan Warga Jemaat, 2(2), 115-134. https://doi.org/10.46445/ejti.v2i2.103

Patandean, Y. E., \& Hermanto, B. W. (2019). TemaTema Theologis Khotbah Yesus Di Bukit Dalam Injil Matius 5:1-7:29. Evangelikal: Jurnal Teologi Injili Dan Pembinaan Warga Jemaat, $\quad 3(2)$, 123-135. https://journal.sttsimpson.ac.id/index.php/EJTI/ article/view/140

Peters, G. W. (2006). Teologi Alkitabiah tentang Pekabaran Injil. Gandum Mas.

Pieris, A. (1996). Berteologi Dalam Konteks Asia. Kanisius.

Piper, J. (2003). Jadikan Sekalian Bangsa Bersukacita. Lembaga Literatur Baptis.

Rahardjo, M. D. (1996). Ekonomi dan Ekologi dalam Perspektif Islam. In J. Banawiratma (Ed.), Iman, 
Ekonomi \& Ekologi: Refleksi Lintas Ilmu dan Lintas Agama (pp. 51-68). Kanisius.

Rowe, C., \& Schofield, M. (2001). Sejarah Pemikiran Politik Yunani dan Romawi. PT RajaGrafindo Persada.

Schweitzer, D. (1999). The Great Depression, The Respopns of North American Theologians. In G. Baum (Ed.), The Twentieth Century: A Theological Overview. Orbis Books.

Setiawan, D. E. (2018). Refleksi Pastoral terhadap Konsep Keselamatan dalam Universalisme Ditinjau dari Soteriologi Kristen. Fidei: Jurnal Teologi Sistematika Dan Praktika, 1(2), 250 269. https://doi.org/10.34081/270031

Song, C.-S. (1979). Third-Eye Theology, Theology in Formation in Asia Settings. Orbis Books.

Stassen, G. H. (1992). Just Peacemaking, Transforming Initiatives for Justice and Peace. Westminster/John Knox Press.

Suharyo, I. (1987). Berbahagialah Orang yang Miskin Di Hadapan Allah Karena Merekalah yang Empuna Kerajaan Surga (Mat. 5:3). In J. Banawiratma (Ed.), Kemiskinan dan Pembebasan. Kanisius.

Susanto, Herry. (2019). Gereja Sebagai Umat Allah dan Rekan Negara. Jurnal Jaffray, 17(1), 3556. https://doi.org/https://10.25278/jj.v17i1.298

Susanto, Hery. (2019). Gereja yang Berfokus pada Gerakan Misioner. FIDEI: Jurnal Teologi
Sistematika Dan Praktika, 2(1), 62-83.

Tobar, M., Kasnawi, M. T., \& AT., M. R. (2020). Hubungan Antar Strata Sosial dalam Masyarakat Modern (Kasus Rampanan Kapa' dalam Masyarakat Tana Toraja). Hasanuddin Journal of Sociology, 2(1), 17-34.

Tomatala, Y. (2003). Teologi Misi, Suatu Dogmatika Tentang Misi, Penginjilan dan Pertumbuhan Gereja. YT Leadership Foundation.

Tridarmanto, Y. (2013). Hermeneutika Perjanjian Baru. Kanisius.

Voss Roberts, M. (2019). Kenotic Gestures. Interreligious Studies and Intercultural Theology, 3(1-2), 198-218. https://doi.org/10.1558/isit.36643

Walzer, M. (1983). Spheres of Justice, A Defense of Pluralism and Equality. Basic Books, Inc.

Wibowo, H. S. (2015). Gereja Memperhatikan Orang Miskin sebagai Relevansi dan Kontemplasi Substansi Evangelium: Refleksi Kritis atas Dokumen Evangelii Gaudium. Jurnal Sosial Humaniora, 8(1), 77-94.

Yewangoe, A. A. (2015). Theologia Crucis di Asia (Vol. 53, Issue 9). BPK Gunung Mulia.

Zuhdiyaty, N. (2017). Analisis Faktor-Faktor yang Mempengaruhi Kemiskinan di Indonesia Selama Lima Tahun Terkahir (Studi Kasus pada 33 Provinsi). Jurnal Jibeka, 11(2), 27-31. 